\title{
Use of sludge ash from drinking water treatment plant in hydraulic mortars
}

\author{
Kevin Bohórquez González ${ }^{\mathrm{a}}$, Emmanuel Pacheco ${ }^{\mathrm{a}}$, Andrés Guzmán ${ }^{\mathrm{b}, *}$, Yoleimy Avila Pereira ${ }^{\mathrm{c}}$, \\ Heidis Cano Cuadro ${ }^{\mathrm{d}}$, Javier A.F. Valencia ${ }^{\mathrm{e}}$ \\ ${ }^{a}$ Department of Chemical Engineering, Universidad del Atlántico, Carrera 30 N 8- 49 Puerto Colombia, Atlántico, Colombia \\ ${ }^{\mathrm{b}}$ Department of Civil and Environmental Engineering, Universidad del Norte, km 5 Vía Puerto Colombia, Área Metropolitana de Barranquilla, Colombia \\ ${ }^{\mathrm{c}}$ Instituto Superior Técnico, Universidade de Lisboa, Av. Rovisco Pais, 1049-001 Lisboa, Portugal \\ ${ }^{\mathrm{d}}$ Department of Civil and Environmental Engineering, Universidad de la Costa, Calle 58\#55-66, Barranquilla, Atlántico 080002, Colombia \\ e Postgraduate Program in Structural Engineering and Construction (PECC), Predio SG-12 Campus Darcy Ribeiro, University of Brasília, Brasilia-DF CEP 70910-900, \\ Brazil
}

\section{A R T I C L E I N F O}

\section{Keywords:}

Supplementary cementitious material

Sludge ash

Compressive strength

Characterization

Construction materials

\begin{abstract}
A B S T R A C T
The present study investigated the use of sludge ash from water treatment plants as supplementary cementing material, elaborating hydraulic mortars with different levels of cement replacement by sludge ash (10 wt $\%$ and $30 \mathrm{wt} \%)$ and different temperatures of calcination $\left(600{ }^{\circ} \mathrm{C}\right.$ and $\left.800{ }^{\circ} \mathrm{C}\right)$. Characterization of sludge ash and mortars includes XRF, XRD, particle size distribution by laser diffraction, compressive strength, and SEM-EDS. The results show that $\mathrm{SiO}_{2}, \mathrm{Al}_{2} \mathrm{O}_{3}$, and $\mathrm{Fe}_{2} \mathrm{O}_{3}$ compose $90 \%$ of the sludge ash, and it has potential pozzolanic activity. It is evidenced that there is a significant influence of the variable ratio of sludge ash:cement in the compressive strength of the mortar cubes over other variables. Overall, this study showed that the sludge ash could be considered as a viable and sustainable alternative for the construction sector. Despite the benefits of the suggested replacement, the presence of amorphous $\mathrm{SiO}_{2}$ requires a review of long-time chemical behavior.
\end{abstract}

\section{Introduction}

Nowadays, industries are implementing sustainable and ecological processes, recognizing the improvement in resource productivity through a circular economy (CE) system. This system aims to give added value to products while reusing or eliminating waste [1]. The increase in demand in construction materials (e.g. cement), shows the need to develop new alternatives from different sources, since traditional production has considerable environmental impacts because of natural resources consumption and $\mathrm{CO}_{2}$ high output [2,3], therefore, the construction industry has a marked challenge from the United Nations Environment Program Sustainable Building and Climate Initiative (UNEP-SBCI) which consists in developing a new material with low $\mathrm{CO}_{2}$ emissions and eco-efficient [4], which has led this industry as the main user of waste worldwide [5], managing processes from CE system.

Among the waste used as a cement substitute is the sludge ash (SA) found in drinking water treatment plants, which is produced by the calcination of dry sludge (DS), achieving a $90 \%$ reduction in volume. The sludge, as it is generated in the sedimentation stage in the drinking water treatment plants, requires adequate final disposal because it has undesirable chemical properties and contain dangerous and toxic substances that cause adverse effects on human health and the environment [6-9]. Studies have shown that aluminum, an element present in the coagulants used in the water purification process, can be toxic [10] and in high concentrations becomes a risk factor for Alzheimer's disease [11].

The pozzolanic activity has been found in SA through various studies [12-14], showing its use as a mineral additive. The literature describes that it is possible to get the same strength observed in the reference concrete (100\% Portland cement), reducing cement consumption by $37-200 \mathrm{~kg} / \mathrm{m}^{3}$ in concretes using SA [13]. Inclusion of SA in mortars as supplementary cement material (SCM) $(5,10,15,20$, 25 and $30 \%$ of cement mass) increases the porosity which influences all the physical and mechanical properties [15], keeping unaffected the general condition of mortars related to performance on fresh and hardened states [13]. The present study aims to determine the influence of the calcination temperature and the percentage of cement substitution by SA on the compressive strength of hydraulic mortars performing a complete factorial experimental design using inferential statistics and characterizing the supplementary cementing material by X-ray diffraction (XRD) and X-ray fluorescence (XRF). Also, its particle size is described by laser diffraction (LD), and the mortars prepared are

\footnotetext{
* Corresponding author.

E-mail addresses: kevbohorquez@gmail.com (K. Bohórquez González), emmanuel7070@hotmail.com (E. Pacheco), faguzman@uninorte.edu.co (A. Guzmán), yoleimy.pereira@tecnico.ulisboa.pt (Y. Avila Pereira), heidycano@gmail.com (H. Cano Cuadro), jaaandresforero@gmail.com (J.A.F. Valencia).
} 
analyzed by SEM coupled to EDS.

\section{Materials and methods}

A description of materials and standards implemented in this research is presented below.

\subsection{Cement and $S A$}

The following materials were used: Ordinary Portland cement (OPC CEM 1), produced by ARGOS, according to the standard NTC 121 [16] and ASTM C-1157 [17]. SA from a water treatment plant located in Barranquilla, Colombia. Its source of water collection is the Magdalena River. The SA sampling was carried out between August and September, a period with scarce rainfall.

\subsection{Aggregate and water}

In this study, one type of natural sand from Santo Tomas - Atlántico, Colombia, was characterized complying ASTM C778 [18] besides tap water was used, complying with Colombian regulations for chemical, microbiological and physical characteristics for drinking water [19].

\subsection{Mix design}

The mortar mixture types were selected following an experimental factorial design $2^{\mathrm{k}}$, where $\mathrm{k}=2$, resulting in 4 combinations. The exponent represents the factors of calcination temperature of the sludge and percentage of cement replaced by SA, and the base corresponds to the low and high test levels for each factor; temperature levels were $600{ }^{\circ} \mathrm{C}$ and $800^{\circ} \mathrm{C}$ and the percentage of cement substitution by SA 10 $\%$ and $30 \%$ (by weight). Factor values were determined from the literature review $[20,21]$. The combinations obtained from the experimental design were the following: CM1 $\left(10 \%-600{ }^{\circ} \mathrm{C}\right)$, CM2 $(10 \%$ $\left.-800{ }^{\circ} \mathrm{C}\right)$, CM3 $\left(30 \%-600{ }^{\circ} \mathrm{C}\right)$ and $\mathrm{CM} 4\left(30 \%-800{ }^{\circ} \mathrm{C}\right)$ and the watercement (W/C) ratio used was 0.594 (above the standardized value of 0.485; explained further in Section 3.1).

The preparation of the mortars was carried out according to the standard ASTM C109 [22]. Table 1 shows the materials used for each mix: a) mortar cubes, including SA, and b) control mortar cubes, including only Portland cement (PC).

\subsection{Sample preparation and test methods}

For this research, sampling in the drinking water treatment plant allowed recovering $45 \mathrm{~kg}$ of sludge with a moisture content of $66.7 \%$. The sludge sample was first dried at a room temperature of $32{ }^{\circ} \mathrm{C}$ for $96 \mathrm{~h}$ (Fig. 1a), attaining a weight of $15 \mathrm{~kg}$ of dry sludge. The mass yield of the sludge was $33.33 \%$ on a dry base (Fig. 1b). DS was ground in a Holmes mill, model 201XL using a mesh No. 8, then calcined in a Carbolite ash oven model AAF $11 / 18$ at temperatures of $600{ }^{\circ} \mathrm{C}$ and $800{ }^{\circ} \mathrm{C}\left(\mathrm{SA}_{600}{ }^{\circ} \mathrm{C}\right.$ and $\left.\mathrm{SA}_{800}{ }^{\circ} \mathrm{C}\right)$ with a residence time in the oven of $3 \mathrm{~h}$ (Fig. 1c) [23]. After the calcination, the mass yields, for the ashes got at $600{ }^{\circ} \mathrm{C}$ and $800{ }^{\circ} \mathrm{C}$, were $89.2 \%$ and $87.21 \%$, respectively, with an orange coloration. After this, the pozzolanic activity was determined by the Modified Chapelle test [24] to $\mathrm{SA}_{600}{ }^{\circ} \mathrm{C}$ and $\mathrm{SA}_{800}{ }^{\circ} \mathrm{C}$, which determines, by titration with $0.1 \mathrm{M} \mathrm{HCl}$, the content of $\mathrm{Ca}(\mathrm{OH})_{2}$ not consumed (free content) by the reactive phases present in the SA during $16 \mathrm{~h}$ of reaction at $90 \pm 5^{\circ} \mathrm{C}$ of $2 \mathrm{~g} \mathrm{CaO}$ grade laboratory and one gram of the waste diluted in distilled water.

The chemical composition of the DS and SA was determined with Xray fluorescence (XRF) analysis on an Epsilon 3Lp Panalytical device. The present phases of the SA were determined by X-ray diffraction (XRD) and using an XPert Panalytical Empyrean Series II reference set with a high-speed solid-state detector, with PIXcel 3D data acquisition and using CuK radiation $(0.154187 \mathrm{~nm})$. The crystalline phases were semi quantified using X'pert Highscore software by the Rietveld method [25]. Also, the SA characterization was enhanced through an analysis of particle size by laser diffraction with a Master sizer 2000E equipment that comprises a measuring range between $0.1 \mu \mathrm{m}$ and $1750 \mu \mathrm{m}$. The powder samples were kept in suspension for $10 \mathrm{~min}$ to eliminate the Van der Waals and electrostatic forces between the particles, before their introduction into the equipment.

To study the influence of temperature and the percentage of SA in mortars, a compressive strength test, according to ASTM C109 [22], was carried out on a Controls ${ }^{\circledR}$ mortar cubes tester. Sixty tests were conducted; the order to test the mortar cubes was randomized to guarantee an unbiased response (i.e., compressive strength). Microstructural analysis of the mortars was performed by scanning electron microscopy (SEM), using a Thermoionic SEM JEOL JSM-6490LV, allowing the visualization of physical characteristics as texture, impurities, microcracking, and structural morphology. Also, a semiquantitative analysis of the elemental composition of energy dispersive spectroscopy (EDS), coupled to SEM, was performed.

\subsection{Statistical analysis}

The statistical analysis of the data was carried out using analysis of variance ANOVA of the Minitab ${ }^{\circledR}$ statistical software [26]. Two factors corresponded to the variables temperature and SA:C relation; the response variable was the unconfined compressive strength of the mortar cubes. The interaction between the two factors was then analyzed.

\section{Results and discussion}

\subsection{Characterization of materials}

Chapelle tests resulted in values of 1967.9 and $1543.0 \mathrm{mg}$ of $\mathrm{Ca}$ $(\mathrm{OH})_{2}$ per $\mathrm{g}$ of residue for $\mathrm{SA}_{600^{\circ} \mathrm{C}}$ and $\mathrm{SA}_{800^{\circ} \mathrm{C}}$, which are higher than the minimum limit of $436 \mathrm{mg} \mathrm{Ca}(\mathrm{OH})_{2} / \mathrm{g}$ established by Raverdy et al. [27] to consider a mineral addition as a pozzolanic material. These results let us define both ashes as pozzolanic. Ahmad et al. [28] also bring this classification through the direct Chapelle test to identify the pozzolanic activity in the sludge generated by the backwash of the filters calcined at $800{ }^{\circ} \mathrm{C}$ in Ghaziabad, India, with a test result of $560 \mathrm{mg} \mathrm{Ca}(\mathrm{OH})_{2} / \mathrm{g}$ of residue.

Table 2 shows the chemical composition of the DS, and SA calcined at $600{ }^{\circ} \mathrm{C}$ and $800{ }^{\circ} \mathrm{C}$. It is observed that the SD and SA contain the principal oxides present in cementing materials such as $\mathrm{SiO}_{2}, \mathrm{Al}_{2} \mathrm{O}_{3}$, $\mathrm{Fe}_{2} \mathrm{O}_{3}$, and $\mathrm{CaO}$; also, there are no significant differences between concentrations obtained for the SA treated at $600{ }^{\circ} \mathrm{C}$ and $800^{\circ} \mathrm{C}$. Simultaneously, the approximate composition limits of oxides for

Table 1

Cementing mixture types and material quantities used in mortar cubes preparation.

\begin{tabular}{|c|c|c|c|c|c|c|}
\hline Mixture type & $\mathrm{SA}+\mathrm{C}(\mathrm{g})$ & Sand $(g)$ & Water $(\mathrm{ml})$ & $\mathrm{W} / \mathrm{C}$ & SA (g) & $C(g)$ \\
\hline Cementing Mix - Mod 1 (CM1) & 1060 & 2915 & 629.64 & 0.594 & 106 & 954 \\
\hline Cementing Mix - Mod 2 (CM2) & 1060 & 2915 & 629.64 & 0.594 & 106 & 954 \\
\hline Cementing Mix - Mod 3 (CM3) & 1060 & 2915 & 629.64 & 0.594 & 318 & 742 \\
\hline Cementing Mix - Mod 4 (CM4) & 1060 & 2915 & 629.64 & 0.594 & 318 & 742 \\
\hline Cementing Mix - Control (CM) & - & 2915 & 629.64 & 0.594 & - & 1060 \\
\hline
\end{tabular}




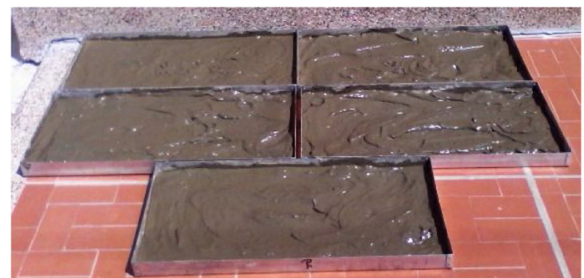

(a)

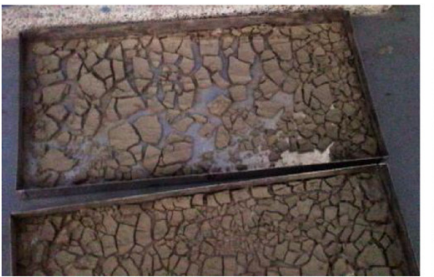

(b)

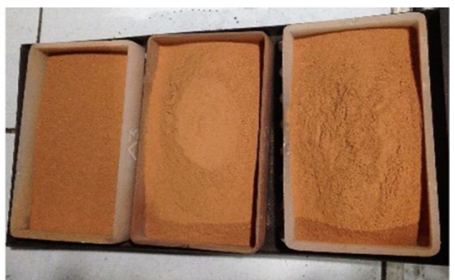

(c)

Fig. 1. Sludge from the drinking water treatment plant. (a) Dried in room temperature, (b) Appearance of sludge after drying at room temperature, (c) Sludge calcined at $600{ }^{\circ} \mathrm{C}$ and $800{ }^{\circ} \mathrm{C}$.

Table 2

Chemical composition of DS and SA calcined at $600{ }^{\circ} \mathrm{C}$ and $800{ }^{\circ} \mathrm{C}$.

\begin{tabular}{|c|c|c|c|c|}
\hline \multirow[t]{2}{*}{ Oxide } & \multicolumn{4}{|c|}{ \%Mass } \\
\hline & DS & $\mathrm{SA}_{600{ }^{\circ} \mathrm{C}}$ & $\mathrm{SA}_{800}{ }^{\circ} \mathrm{C}$ & Cement [38] \\
\hline $\mathrm{SiO}_{2}$ & 60.91 & 60.39 & 60.31 & $17-25$ \\
\hline $\mathrm{Al}_{2} \mathrm{O}_{3}$ & 19.72 & 20.81 & 20.121 & $3-8$ \\
\hline $\mathrm{Fe}_{2} \mathrm{O}_{3}$ & 11.59 & 11.11 & 10.8715 & $0.5-6.0$ \\
\hline $\mathrm{K}_{2} \mathrm{O}$ & 2.42 & 2.33 & 2.1275 & $0.4-0.6$ \\
\hline $\mathrm{CaO}$ & 1.481 & 1.53 & 1.991 & $60-67$ \\
\hline $\mathrm{MgO}$ & 1.47 & 1.46 & 1.269 & 4.0 \\
\hline $\mathrm{TiO}_{2}$ & 0.96 & 0.92 & 0.916 & $0.26-0.90$ \\
\hline $\mathrm{SO}_{3}$ & 0.23 & 0.25 & 0.2005 & $1-3$ \\
\hline
\end{tabular}

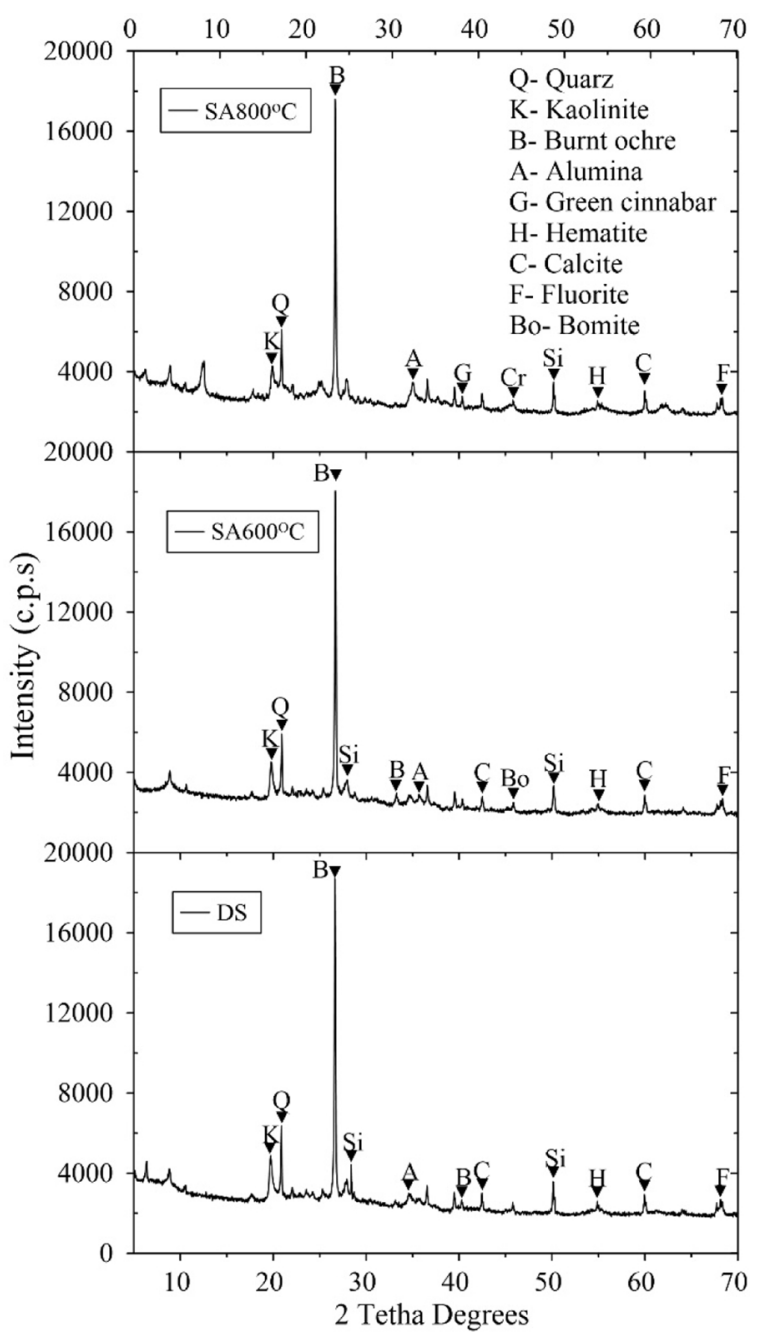

Fig. 2. Diffractogram of DS, treated at $600{ }^{\circ} \mathrm{C}\left(\mathrm{SA} 600{ }^{\circ} \mathrm{C}\right.$ ), and $800{ }^{\circ} \mathrm{C}$ $\left(\mathrm{SA} 800^{\circ} \mathrm{C}\right)$.
Table 3

Particle size by volume for the SA.

\begin{tabular}{lll}
\hline $\mathrm{D}$, volume percent & \multicolumn{2}{l}{ Particle size, $\mu \mathrm{m}$} \\
\cline { 2 - 3 } & $\mathrm{SA}_{600^{\circ} \mathrm{C}}$ & $\mathrm{SA}_{800^{\circ} \mathrm{C}}$ \\
\hline $\mathrm{D}(0.1)$ & 6.638 & 6.138 \\
$\mathrm{D}(0.5)$ & 112.718 & 98.217 \\
$\mathrm{D}(0.9)$ & 590.375 & 570.860 \\
Residual \% & 0.748 & 0.650 \\
\hline
\end{tabular}

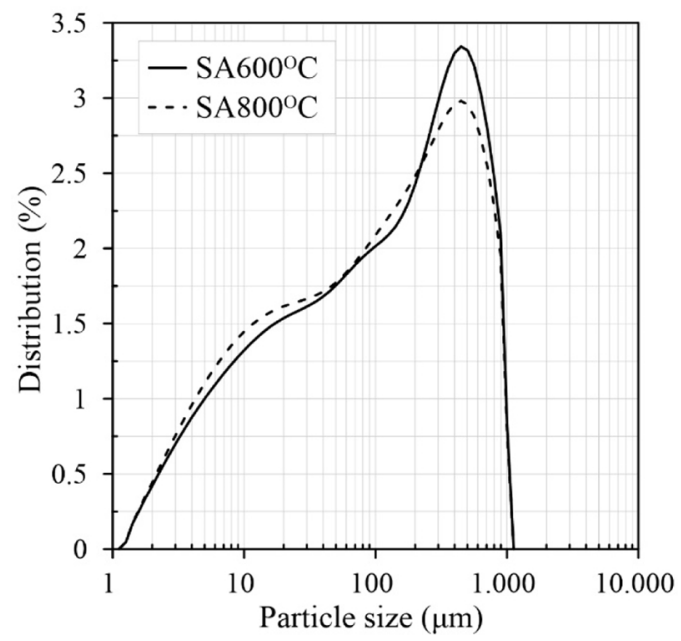

Fig. 3. Particle size distribution of SA at $600{ }^{\circ} \mathrm{C}$ and SA at $800{ }^{\circ} \mathrm{C}$.

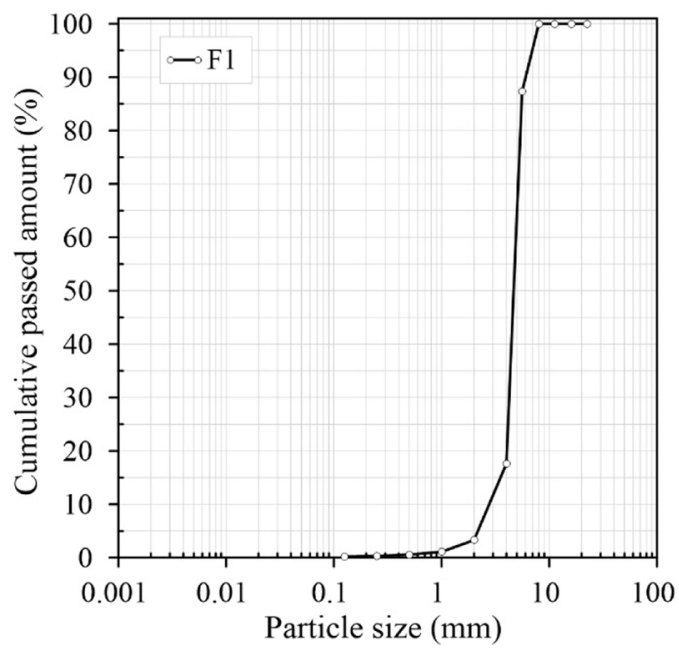

Fig. 4. Granulometry curve of the fine aggregate. 
Table 4

Results for unconfined compressive strength in mortar cubes for each cementing mixtures (CM) by age.

\begin{tabular}{|c|c|c|c|c|c|c|c|c|c|c|c|c|c|c|c|}
\hline \multirow[t]{3}{*}{ Ages (days) } & \multicolumn{12}{|c|}{ Cementing mixtures (CM) with SA addition (MPa) } & \multicolumn{3}{|l|}{$\mathrm{CM}$} \\
\hline & \multicolumn{3}{|l|}{ CM 1} & \multicolumn{3}{|l|}{ CM 2} & \multicolumn{3}{|l|}{ CM 3} & \multicolumn{3}{|l|}{ CM 4} & \multirow[b]{2}{*}{$\mathrm{fm}$} & \multirow[b]{2}{*}{ av } & \multirow[b]{2}{*}{$\mathrm{Sd}^{*}$} \\
\hline & $\mathrm{fm}$ & av & $\mathrm{Sd}^{*}$ & $\mathrm{fm}$ & av & $\mathrm{Sd}^{*}$ & $\mathrm{fm}$ & av & $\mathrm{Sd}^{*}$ & $\mathrm{fm}$ & av & $\mathrm{Sd}^{*}$ & & & \\
\hline \multirow[t]{3}{*}{1} & 9.24 & 9.00 & 0.34 & 6.69 & 6.80 & 0.15 & - & 4.12 & 0.14 & - & 4.41 & 0.28 & 9.16 & 9.30 & 0.20 \\
\hline & 8.76 & & & 6.90 & & & 4.02 & & & 4.61 & & & - & & \\
\hline & - & & & - & & & 4.22 & & & 4.21 & & & 9.44 & & \\
\hline \multirow[t]{3}{*}{7} & 15.09 & 14.76 & 0.47 & 16.12 & 16.31 & 0.26 & 6.81 & 7.13 & 0.45 & 6.39 & 6.63 & 0.34 & 12.29 & 12.80 & 0.71 \\
\hline & 14.42 & & & 16.49 & & & - & & & 6.87 & & & - & & \\
\hline & - & & & - & & & 7.45 & & & - & & & 13.30 & & \\
\hline \multirow[t]{3}{*}{14} & 14.81 & 15.10 & 0.41 & 16.82 & 17.98 & 0.84 & 9.93 & 9.05 & 0.74 & 10.12 & 9.00 & 0.89 & 15.10 & 15.94 & 0.81 \\
\hline & 15.39 & & & - & & & - & & & 7.87 & & & 16.78 & & \\
\hline & - & & & 19.14 & & & 8.17 & & & - & & & - & & \\
\hline \multirow[t]{3}{*}{28} & - & 17.10 & 0.51 & 20.05 & 19.81 & 0.34 & - & 9.96 & 0.58 & 9.94 & 9.90 & 0.06 & - & 20.35 & 0.95 \\
\hline & 16.74 & & & 19.57 & & & 9.55 & & & 9.86 & & & 19.18 & & \\
\hline & 17.46 & & & - & & & 10.37 & & & - & & & 21.51 & & \\
\hline
\end{tabular}

Note: fm: unconfined compressive strength [MPa]; av: average [MPa]; Sd: Standard deviation [MPa].

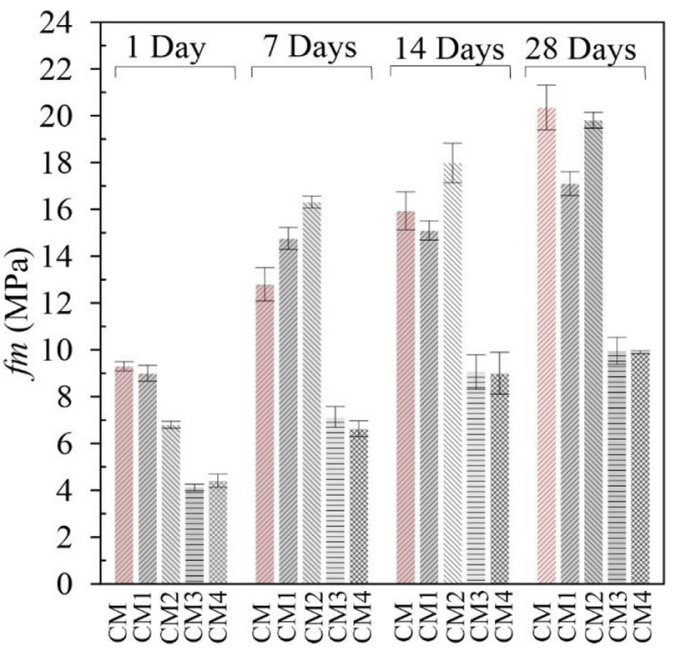

Fig. 5. Compressive strength for each cementing mixture at different curing ages.

Table 5

Variance analysis results.

\begin{tabular}{llllll}
\hline Source & $\mathrm{DF}^{\mathrm{a}}$ & $\mathrm{SS}^{\mathrm{b}}$ & $\mathrm{MS}^{\mathrm{c}}$ & $\mathrm{F}^{\mathrm{d}}$ & $\mathrm{P}^{\mathrm{e}}$ \\
\hline Ratio SA:C & 1 & 401.153 & 401.153 & 31.24 & 0.000 \\
Temperature & 1 & 2.657 & 2.657 & 0.21 & 0.653 \\
Ratio SA:C $\times$ Temperature & 1 & 3.458 & 3.458 & 0.27 & 0.608 \\
Error & 28 & 359.564 & 12.842 & & \\
Total & 31 & 766.832 & & & \\
$\mathrm{~S}=3.583$ & $\mathrm{R}-\mathrm{sq}=53.11 \%$ & R-sq (adj) $=48.09 \%$ & \\
& & & &
\end{tabular}

${ }^{\mathrm{a} D F}$ : Degree of freedom ${ }^{\mathrm{b}} \mathrm{SS}$ : Sum of squares ${ }^{\mathrm{c}} \mathrm{MS}$ : Mean squared ${ }^{\mathrm{d}} \mathrm{F}$ : Statistical value $F^{\mathrm{e}} \mathrm{P}$ : Statistical value $\mathrm{P}$.

Portland cement is shown [29]. If the approximated data of cement composition is compared to the SA composition, it is observed that $\mathrm{SiO}_{2}, \mathrm{Al}_{2} \mathrm{O}_{3}$, and $\mathrm{Fe}_{2} \mathrm{O}_{3}$ oxides have high concentrations at both temperatures; the percentage represents $90 \%$ of sludge ash composition, which allows classifying the material as pozzolan class $\mathrm{F}$ [30]. The results from the chemical composition of the sludge calcined at $600{ }^{\circ} \mathrm{C}$ and $800^{\circ} \mathrm{C}$ (Table 2) are similar to those of Gastaldini et al. [13] who used SA as a mineral addition in the manufacture of mortars, characterizing by XRF the ashes obtained at $600{ }^{\circ} \mathrm{C}$, in which the percentage of $\mathrm{SiO}_{2}, \mathrm{Al}_{2} \mathrm{O}_{3}$ and $\mathrm{Fe}_{2} \mathrm{O}_{3}$ also exceeds $90 \%$.

The XRD results for the SA treated at $600{ }^{\circ} \mathrm{C}, 800{ }^{\circ} \mathrm{C}$, and DS without thermal treatment, are shown in Fig. 2. It is observed that the main components in the DS are quartz (89.9\%) and alumina (5.1\%). There are also small amounts of eskolaite, fluorite, hematite, calcite, and kaolinite. The diffractograms of $\mathrm{SA}_{600^{\circ} \mathrm{C}}$ shows that the most significant components are quartz ( $96 \%$ ) and alumina ( $2 \%$ ), finding a decrease in the percentage of alumina by $3 \%$ and an increase in the proportion of quartz by $6 \%$ related to the DS composition. The diffractograms of $\mathrm{SA}_{800^{\circ} \mathrm{C}}$ shows quartz $(94.4 \%)$ and alumina $(2 \%)$ as predominant components.

The calcination at $800{ }^{\circ} \mathrm{C}$ revealed a decrease of quartz by $1 \%$

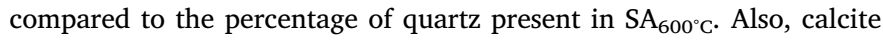
decreases in ash calcined at $800^{\circ} \mathrm{C}$ because it decomposes close to this temperature at atmospheric pressure to produce calcium oxide and carbon dioxide [31]. The results show significant quantities of $\mathrm{SiO}_{2}$ and $\mathrm{Al}_{2} \mathrm{O}_{3}$, responsible for the formation of calcium silicate hydrate (C-S-H) and calcium aluminate hydrate (C-A-H) in the hardened cement paste [32], once they are hydrated.

Regarding the particle size, the $\mathrm{SA}_{600^{\circ} \mathrm{C}}$ and $\mathrm{SA}_{800^{\circ} \mathrm{C}}$ showed a particle diameter between 1 and $1000 \mu \mathrm{m}$. Table 3 shows the results of particle size in volume percent for the $\mathrm{SA}_{600}{ }^{\circ} \mathrm{C}$ and $\mathrm{SA}_{800}{ }^{\circ} \mathrm{C}$. It is observed that $90 \%$ by volume of the analyzed particles had a diameter

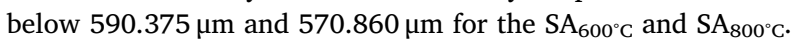

Fig. 3 shows a particle size distribution of SA at $600{ }^{\circ} \mathrm{C}$ and $800^{\circ} \mathrm{C}$. Comparing the obtained data of particle size with the particle size distribution according to the ASTM C 618-17a standard [30], the percentage of analysed ash particles have an approximate diameter below $45 \mu \mathrm{m}$ is $35.078 \%$ and $35.915 \%$, respectively, which are largely consistent with the amount of $34 \%$ reported by the ASTM Standard. With a higher finesse of the particles of the pozzolan material, the density of the mortar mixture will be lower, causing a higher water requirement. Due to this reason and the characteristics of the SA studied, there is an increase in the water requirement and the relation water-cement ratio as per ASTM C109 (standardized water/cement ratio: 0.485).

\subsection{Characterization of aggregates}

In this research, one type of natural siliceous sand was used complying with ASTM C778 - 17 [18]; sand $\left(F_{1}\right)$, with a specific gravity of $2.61 \mathrm{~g} / \mathrm{cm}^{3}$ and fineness modulus of 3.0 . The particle size distribution is shown in Fig. 4.

\subsection{Compressive strength}

Table 4 shows the results for the unconfined compressive strength tests at different curing ages for each of the mortar mixtures as described in Table 1. The results show that the compressive strength increases as the curing time increases, this increase being more significant 

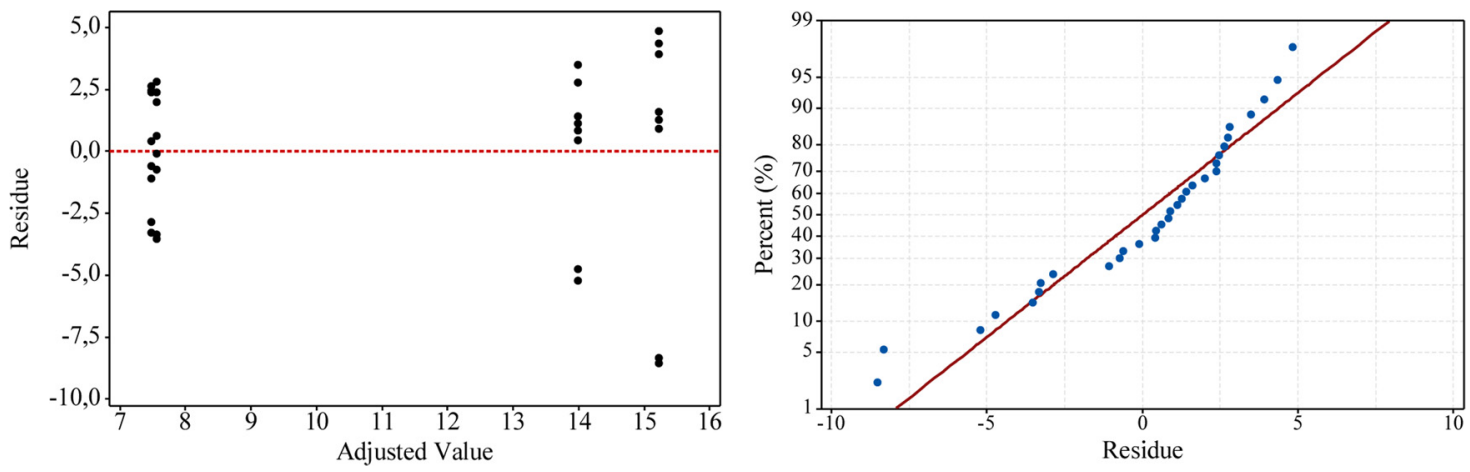

Fig. 6. a) Residue graph for compressive strength data, b) Normal probability plot for the residuals.

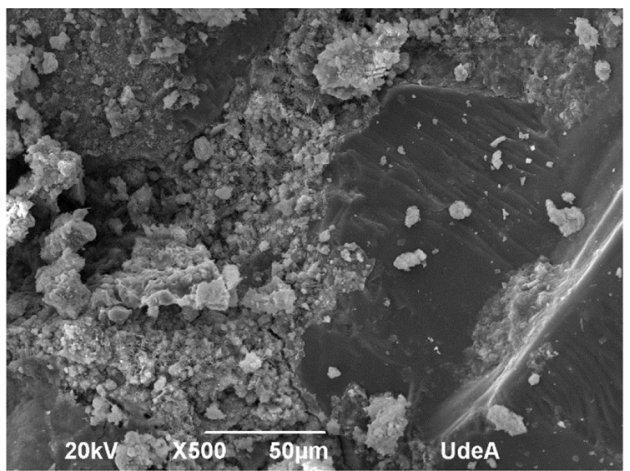

(a)

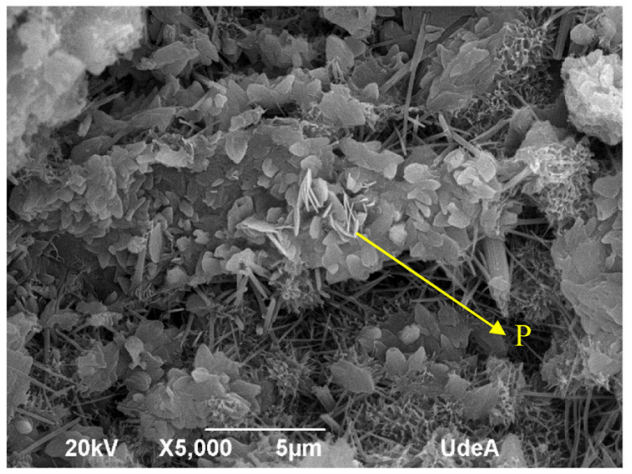

(c)

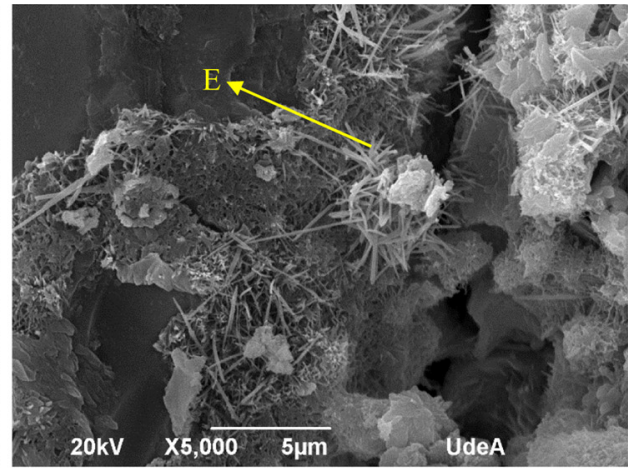

(b)

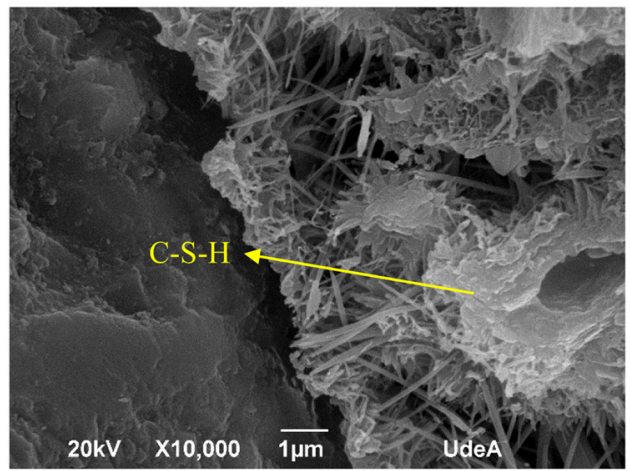

(d)

Fig. 7. Cement hydration products for the CM after 28 days of curing: ettringite (E), portlandite (P), and hydrated calcium silicates (C-S-H).

in the samples CM1 and CM2 compared to the CM. The standard deviations are small, which shows that the results have little dispersion among them. Fig. 5 shows the tendencies of the compressive strength from each of the mortar mixtures with SA compared to the CM. The sample CM3 and CM4 did not develop compressive strengths higher than $10 \mathrm{MPa}$ in any curing age, compared with the control mortar (difference: $48 \%$ ), possibly due to the dilution effect justified by the addition of $30 \%$ of SA; these results are similar to those presented by Carvalho Gomes et al. [33], which in their review article determined a compressive strength reduction between $14-65 \%$ in replacements between $10 \%$ to $30 \%$ of the cement by the supplementary cementitious material.

The CM1 and CM2 samples show a tendency similar to the CM (Control) at 7 and 14 days. The CM2 shows a compressive strength value close to the $\mathrm{CM}$ after 28 days of curing (difference: $0.53 \mathrm{MPa}$ ).

\subsection{Statistical analysis}

Table 5 shows the results of the ANOVA statistical analysis. The statistical P-value for the interaction ratio SA:C $\times$ temperature is 0.608. Therefore, the null hypothesis that all interactions are equal to 0 is not rejected, and it is concluded that the additive model for a two-way ANOVA analysis of variance is credible.

The statistical P-value for the SA:C ratio is 0.000 , meaning that it affects the response variable, that is, the compressive strength of the mortar cubes. The statistical P-value for temperature, 0.653, inferred that its effect on the response variable is little or minimal compared to the SA:C ratio. These results show the direct influence of the SA:C ratio with the mechanical properties of the mortar cubes, while statistically, for the range of temperature tested, it does not significantly influence the mechanical properties of the mortar cubes. A residual plot and a normal probability plot of the residuals were used to check the assumption of equal variances, and thus, to verify normality. Fig. 6a shows the linearity of the data, which shows the effect of the influential data. In Fig. 6b, the points presented are close to the normality line, meaning that there is no evidence of strong deviation from normality.

The replacement of cement with supplementary cementing materials involves a reaction of the portlandite, $\mathrm{Ca}(\mathrm{OH})_{2}$, with the 

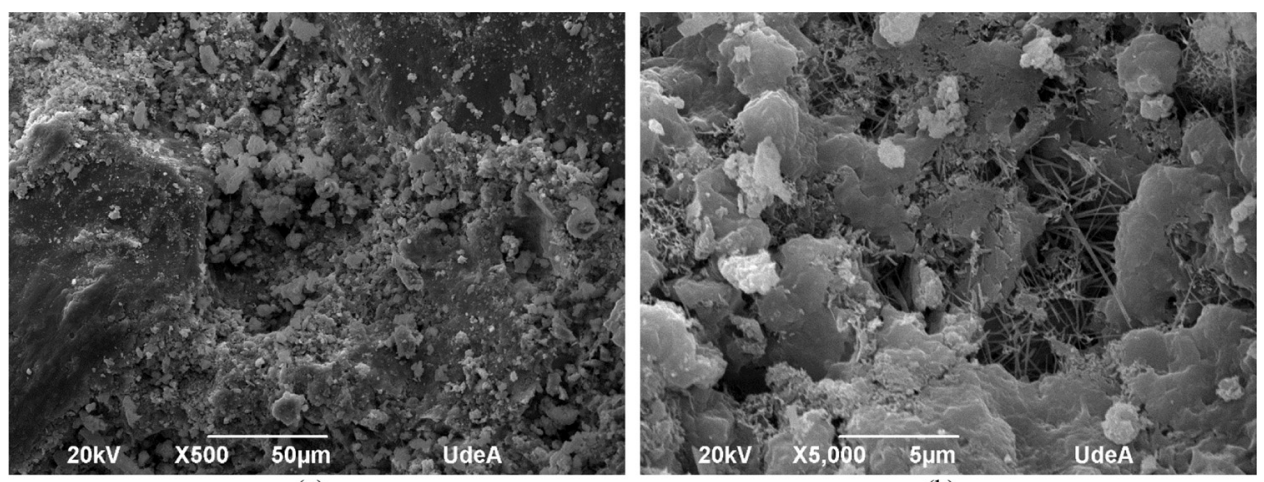

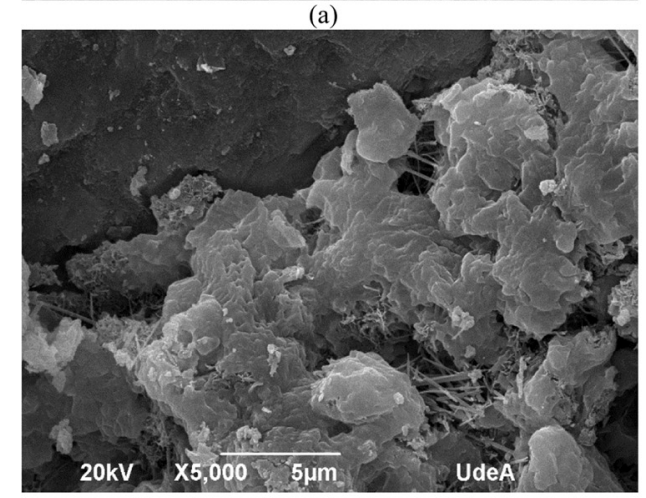

(c)

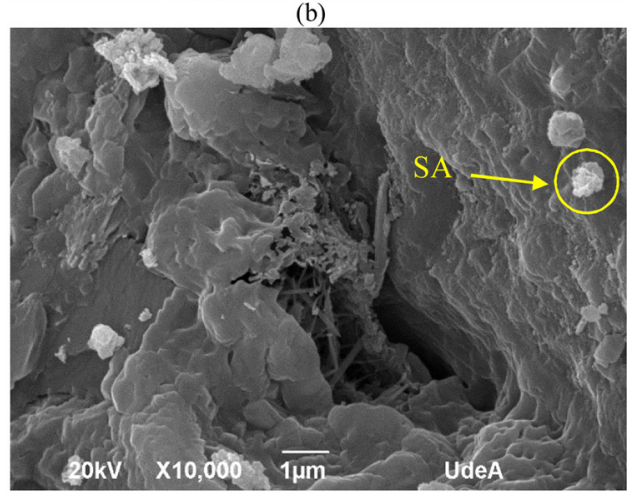

(d)

Fig. 8. Hydration products of the cement for the CM1 sample at 28 days of curing.

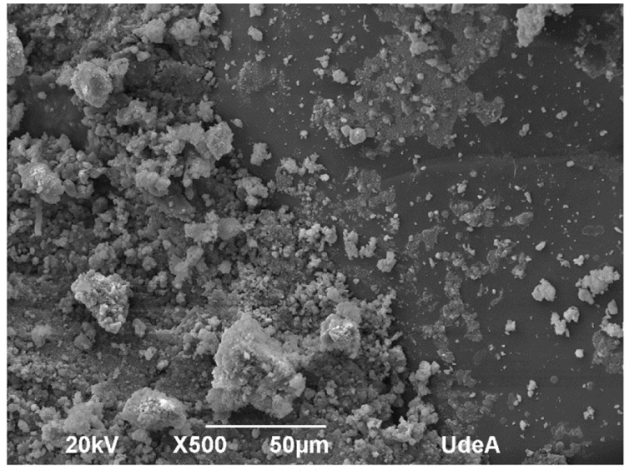

(a)

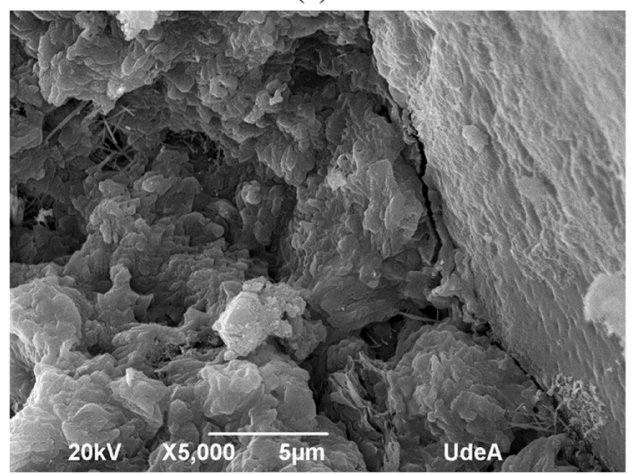

(c)

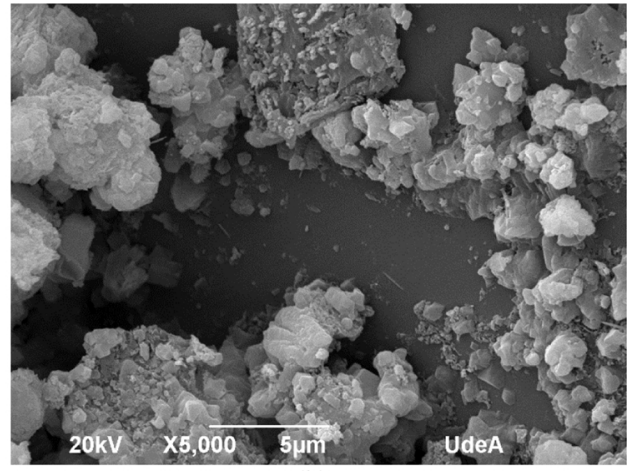

(b)

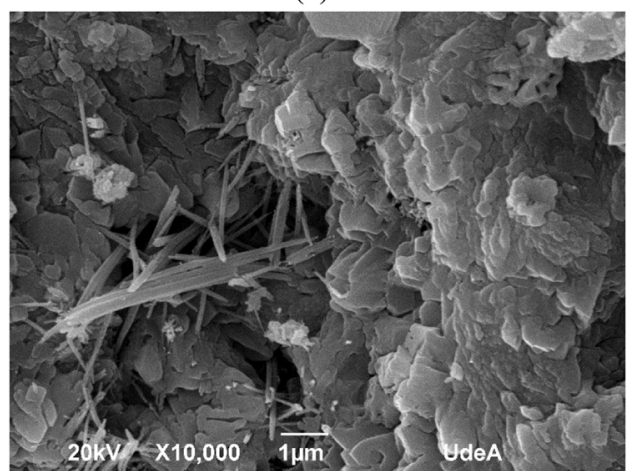

(d)

Fig. 9. Hydration products of the cement for the CM2 sample at 28 days of curing.

amorphous phases of the aluminosilicates present in the SA to produce C-S-H. Sludge calcination at $600{ }^{\circ} \mathrm{C}$ or $800{ }^{\circ} \mathrm{C}$ does not achieve the change from amorphous phases to crystalline phases; therefore, energy expenditure is unnecessary. These characteristics are confirmed by the $\mathrm{XRD}$ results, where the variation of the crystalline phases presents a minimal difference in the diffractograms. These results are consistent with those found by Gastaldini et al. [13] and Hagemann et al. [14]. Regarding quartz, it must be considered the quantification of the amorphous phases to evaluate the long-term chemical performance of mortar mixes, including SA. The amorphous phases of quartz react with 

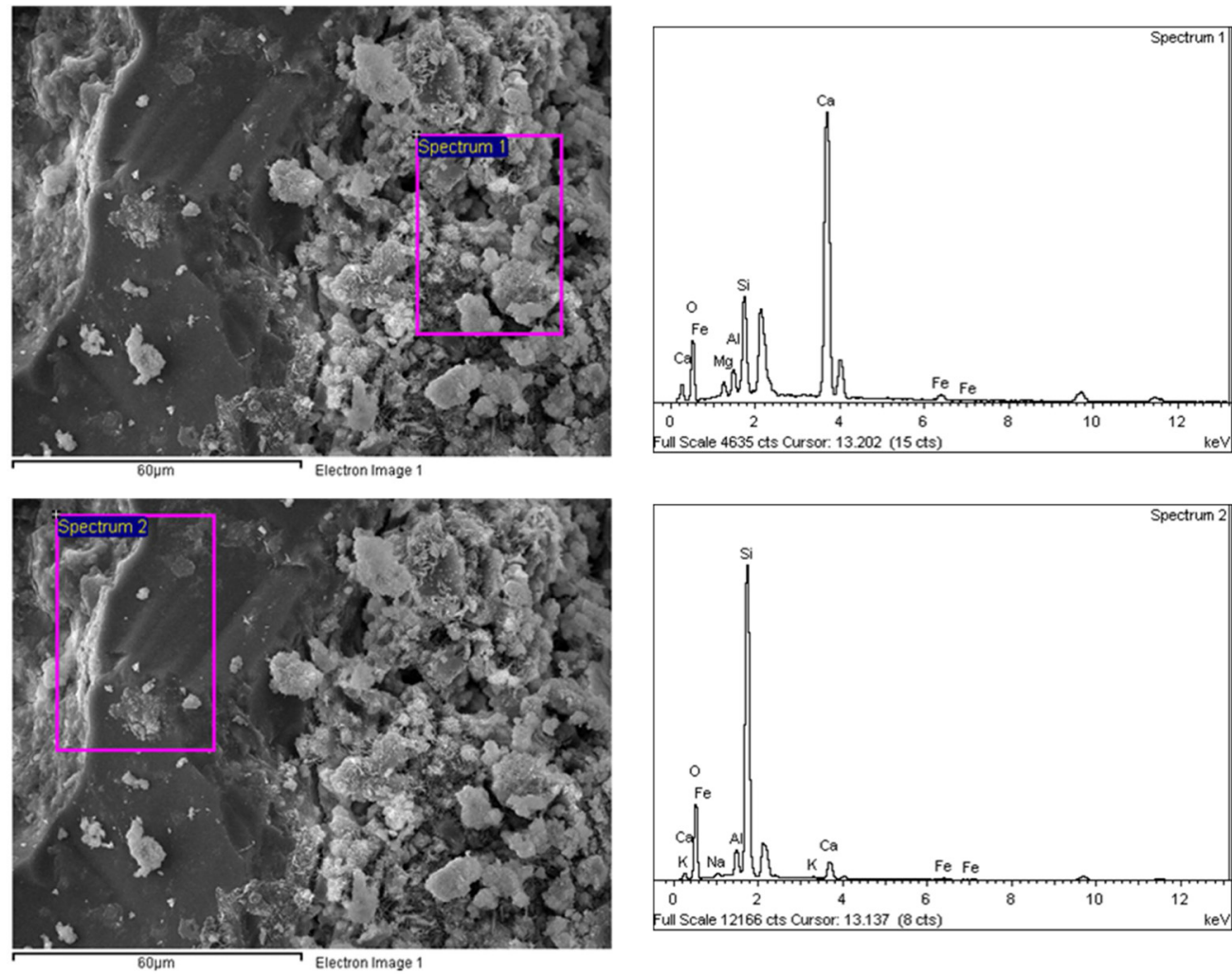

(a)
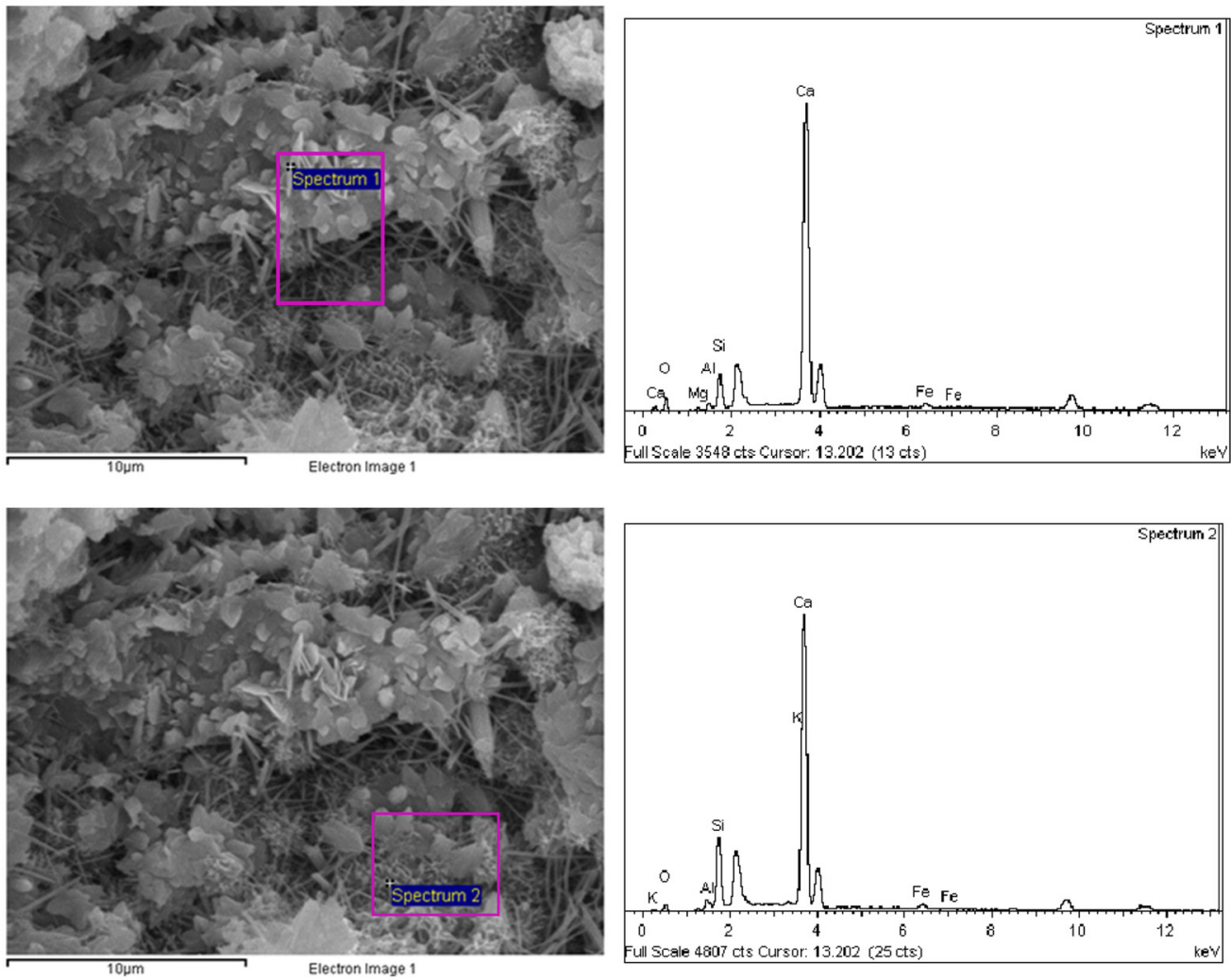

(b)

Fig. 10. EDS analysis for the CM sample at 28 days of curing. 

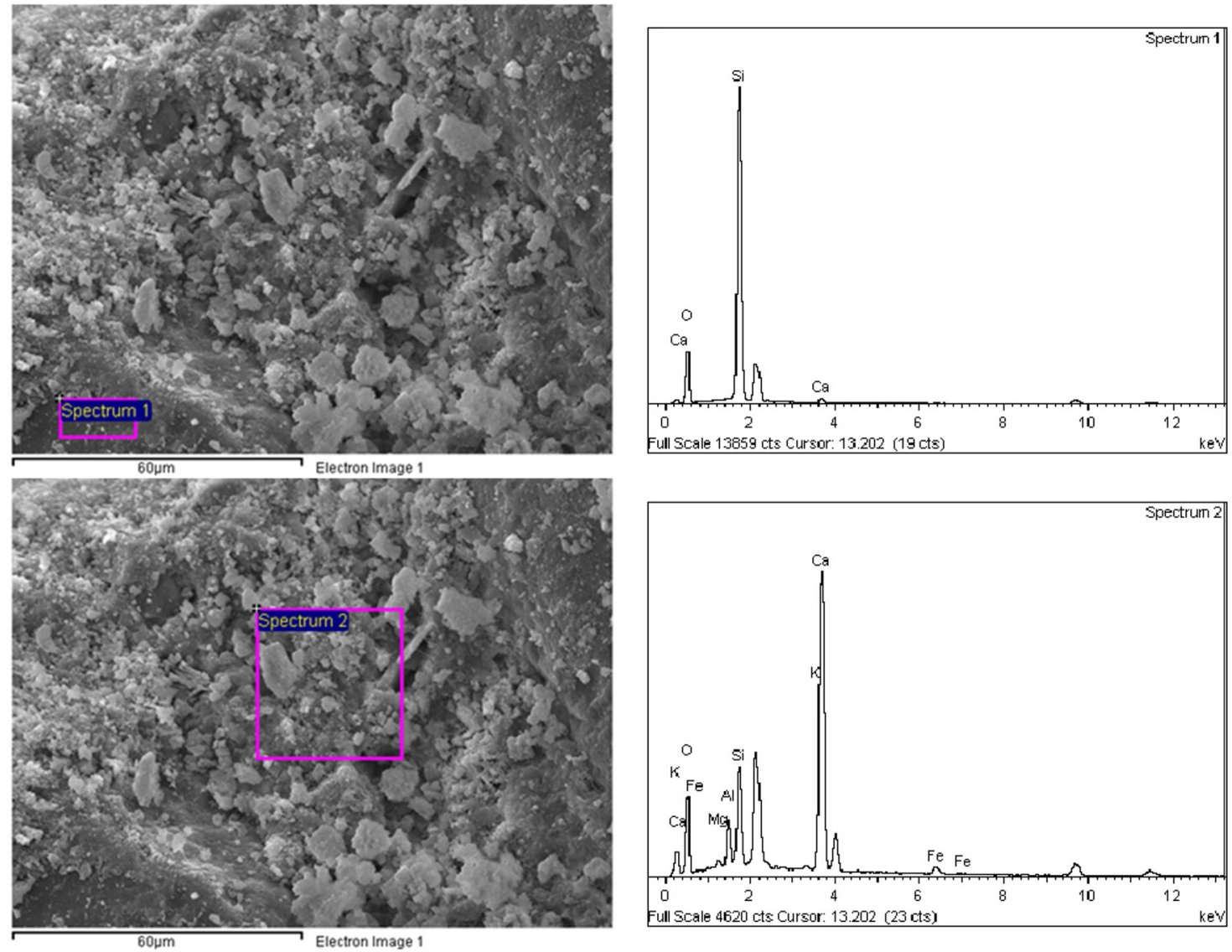

Fig. 11. EDS analysis for sample CM1 at 28 days of curing.

portlandite, resulting in the silica gel that is an expansive compound, source of several pathologies in concrete [34].

\subsection{Microstructural analysis}

Fig. 7a shows the SEM micrographs for the CM. Fine needles of ettringite ( $\mathrm{E}$, hydrated calcium sulphoaluminate, Fig. $7 \mathrm{~b}$ ), portlandite plates (P; Calcium hydroxide or $\mathrm{CH}$, Fig. 7c), typical of the cement paste once hydrated, and hydrated calcium silicate amorphous phase (C-S-H, Fig. 7d) are observed.

Figs. 8 and 9 show the microstructures for samples CM1 and CM2. The presence of ettringite and hydrated calcium silicates (C-S-H) is observed in both samples. The portlandite $(\mathrm{CH})$ does not appear which contributes negatively to the chemical stability of the compound, probably because of the pozzolanic reaction that transforms $\mathrm{CH}$ into $\mathrm{C}$ $\mathrm{S}-\mathrm{H}$, improving mechanical properties and filling some of the open pores, confirming the compressive strength results of improved performance of the mortars with SA addition $[35,36]$. It is observed SA as off-white hemispherical particles in the concrete matrix (Figs. 8d and 9 d). Other works show SA morphology as an irregular surface formed by angular particles with low sphericity [36]. Pospíšil et al. [37] found microstructures with ettringite and portlandite crystals forming needle shapes, fibers or fan-shaped agglomerations, and the portlandite crystals forming shapes of boards or chips within a gap-free space.

Fig. 10 shows the SEM-EDS analysis for the CM sample at 28 days of curing. Fig. 10a, spectrum 1, shows $\sim 15 \mu \mathrm{m}$ hemispherical granules formed mainly by Ca (44.4 wt\%) and O (44.94 wt\%); while in spectrum 2 , a grey and flat area is observed, formed mostly by $\mathrm{Si}(43.89 \mathrm{wt} \%)$ and O (46.49 wt\%). Fig. 10b shows the compositional analysis of the observed microstructures. A high percentage of $\mathrm{Ca}(67.20 \mathrm{wt} \%)$ and $\mathrm{O}$ (24.45 wt\%) was found in spectrum 1 , evidencing portlandite (Ca $(\mathrm{OH})_{2}$ ) and for spectrum 2, Ca (72.70 wt $\left.\%\right)$ was shown, O (12.40 wt $\left.\%\right)$,
Si (10.49 wt\%) and $\mathrm{Al}(1.45 \mathrm{wt} \%)$ ratifying the presence of ettringite $\left(\mathrm{Ca}_{6} \mathrm{Al}_{2}\left(\mathrm{SO}_{4}\right)_{3}(\mathrm{OH})_{12} \cdot 26 \mathrm{H}_{2} \mathrm{O}\right)$.

Figs. 11 and 12 show an SEM-EDS analysis performed on samples CM1 and CM2. It is observed that the grey areas (Figs. 11 and 12, spectrum 1) are rich in silicon and oxygen with high percentages by weight of Si (54.98wt\%), O (43.75 wt\%) for sample CM1, and Si $(63.56 \mathrm{wt} \%)$ and $\mathrm{O}(34.869 \mathrm{wt} \%)$ for sample CM2. It is observed that these percentages are higher compared to the CM results, and it can be inferred that there is a particular influence of the SA treated at $600{ }^{\circ} \mathrm{C}$ and $800{ }^{\circ} \mathrm{C}$ in the mortar mixture.

Moreover, there are zones with presence of light grey hemispherical granules and porous texture (Figs. 11 and 12, spectrum 2) conformed mainly by $\mathrm{Ca}(37.48 \mathrm{wt} \%), \mathrm{O}(48.29 \mathrm{wt} \%), \mathrm{Si}(7.51 \mathrm{wt} \%)$ and $\mathrm{Al}$ (3.68 wt\%), for the sample CM1, and Ca (44.21 wt\%), O (47.22 wt\%), Si (5.76 wt\%) and $\mathrm{Al}(1.61 \mathrm{wt} \%)$, for sample CM2. These forms of structures are similar for both types of mixtures, and they are very similar in composition to the ettringite. However, the shape of this microstructure is different compared to the CM sample.

\section{Conclusions}

With this experimental work, the following conclusions can be drawn:

- According to the analysis of XRF and XRD of the samples, $\mathrm{SiO}_{2}$, $\mathrm{Al}_{2} \mathrm{O}_{3}$ and $\mathrm{Fe}_{2} \mathrm{O}_{3}$ represent $90 \%$ of the composition of sludge ash which according to ASTM C618-17a classifies sludge ash as pozzolan material class $\mathrm{F}$, showing the potential of the SA from the drinking water treatment plants to be used as a supplementary cementing material.

- CM1 and CM2 mixtures, which contain the lowest proportion of sludge ash and lowest temperature $\left(10 \%-600^{\circ} \mathrm{C}\right)$, develop a 

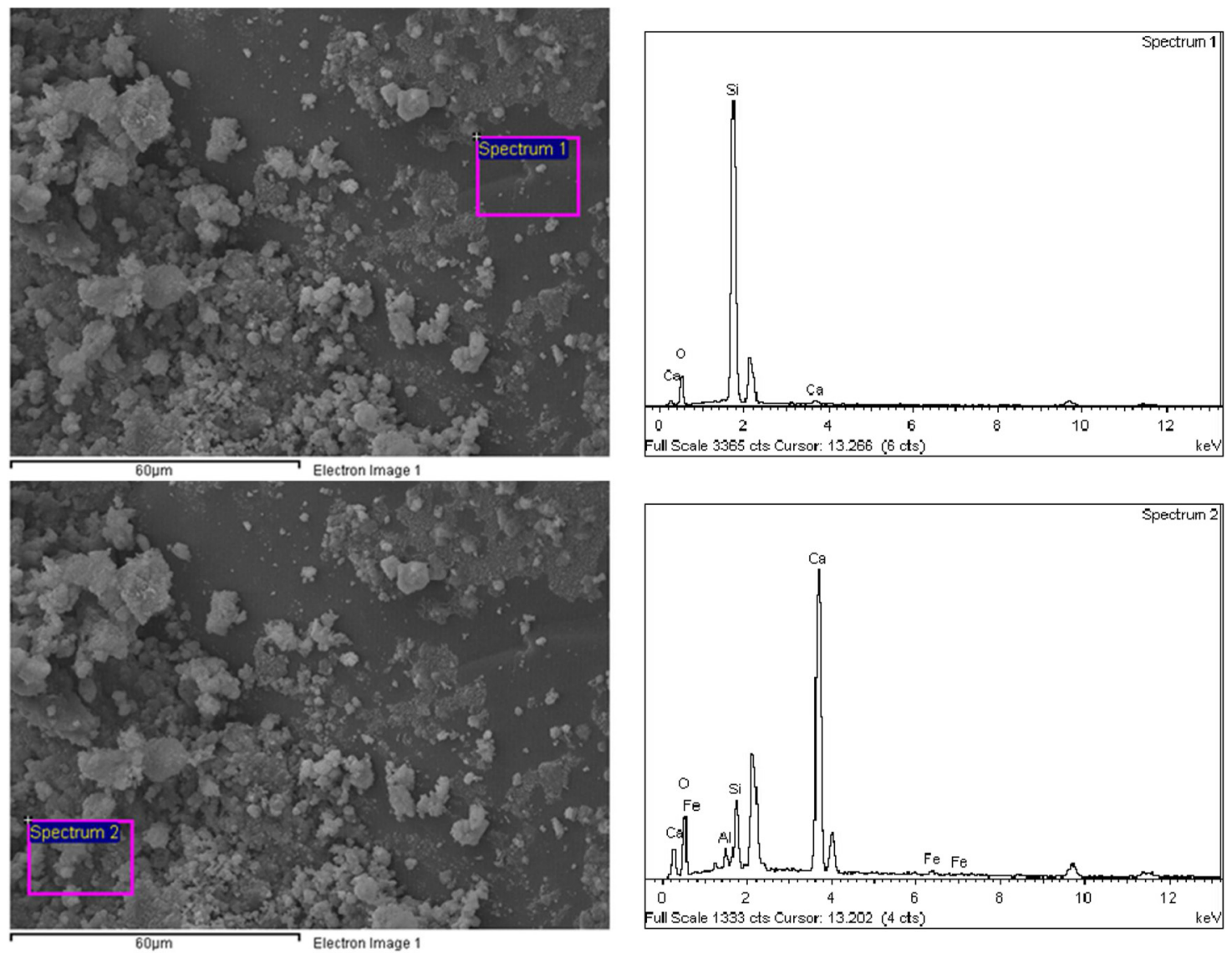

Fig. 12. EDS analysis for CM2 sample at 28 days of curing.

compressive strength similar to the $\mathrm{CM}$ at all ages of curing, showing the feasibility of using SA from the drinking water treatment plant in the construction industry.

- The microstructure revealed that SA mortar shows ettringite and hydrated calcium silicates (C-S-H), probably because of an overtime pozzolanic reaction.

- The statistical analysis of the data shows a more significant influence of the variable ratio of sludge ash:cement in the compressive strength of the mortar cubes compared with the variable temperature.

- The SEM-EDS analysis for CM1 and CM2 resulted in areas rich in silicon and oxygen with high percentages of Si (54.98 wt\%), O (43.75 wt\%) for sample CM1, and Si (63.56 wt\%) and O (34.869 wt \%) for sample CM2. These results are higher compared to the CM composition. This analysis complements XRD results for the SA treated at $600{ }^{\circ} \mathrm{C}, 800{ }^{\circ} \mathrm{C}$, and DS without thermal treatment, where it is observed that the main components in the DS are quartz (89.9 $\%)$ and alumina (5.1\%). It is noticeable that crystalline quartz is desirable and inert, resulting in a stable mix. The use of SA should be cautious regarding reactions between amorphous quartz (not yet quantified) and alkaline compounds of the concrete as $\mathrm{Ca}(\mathrm{OH})_{2}$, causing hydrophilic silica gel and, therefore, resulting in expansion and severe pathologies in concrete when hydrated.

Despite the benefits of the suggested replacement and in the proportions studied, this topic needs more research directed to study the long-time behavior of these type additions with high contents of $\mathrm{SiO}_{2}$ and its associated pathologies (i.e., alkali-silica reaction) according to the quantification of amorphous $\mathrm{SiO}_{2}$.

\section{Funding}

This research did not receive any specific grant from funding agencies in the public, commercial, or not-for-profit sectors.

\section{Data availability}

The raw/processed data required to reproduce these findings cannot be shared at this time as the data also forms part of an ongoing study.

\section{CRediT authorship contribution statement}

Kevin Bohórquez González: Investigation, Formal analysis, Writing - original draft. Emmanuel Pacheco: Investigation, Formal analysis. Andrés Guzmán: Conceptualization, Writing - review \& editing, Validation, Visualization. Yoleimy Avila Pereira: Conceptualization, Methodology, Resources, Supervision, Writing - review \& editing, Visualization, Funding acquisition. Heidis Cano Cuadro: Formal analysis, Methodology, Visualization, Writing - review \& editing. Javier A.F. Valencia: Writing - review \& editing.

\section{Declaration of Competing Interest}

The authors declare that they have no known competing financial interests or personal relationships that could have appeared to influence the work reported in this paper.

\section{Acknowledgments}

Authors thank the Universidad del Norte in Barranquilla for allowing the use of their facilities, and special thanks to the company Saybolt de Colombia, for its collaboration in the execution of the 
characterization tests required for this investigation.

\section{References}

[1] M. Smol, J. Kulczycka, A. Henclik, K. Gorazda, Z. Wzorek, The possible use of sewage sludge ash (SSA) in the construction industry as a way towards a circular economy, J. Clean. Prod. 95 (2015) 45-54, https://doi.org/10.1016/j.jclepro.2015. 02.051 .

[2] J.S. Gregg, R.J. Andres, G. Marland, China: emissions pattern of the world leader in $\mathrm{CO}_{2}$ emissions from fossil fuel consumption and cement production, Geophys. Res. Lett. 35 (2008), https://doi.org/10.1029/2007GL032887.

[3] G. Habert, Environmental impact of Portland cement production, Eco-Efficient Concrete, Elsevier, 2013, pp. 3-25, https://doi.org/10.1533/9780857098993.1.3.

[4] K.L. Scrivener, V.M. John, E.M. Gartner, Eco-Efficient Cements: Potential Economically Viable Solutions for a low- $\mathrm{CO}_{2}$ Cement- Based Materials Industry, United Nations Environment Program, 2016 (Accessed September 17, 2019), http://spiral.imperial.ac.uk/handle/10044/1/51016.

[5] J.M. Franco de Carvalho, T.V. de Melo, W.C. Fontes, J.O. dos S. Batista, G.J. Brigolini, R.A.F. Peixoto, More eco-efficient concrete: an approach on optimization in the production and use of waste-based supplementary cementing materials, Constr. Build. Mater. 206 (2019) 397-409, https://doi.org/10.1016/j. conbuildmat.2019.02.054

[6] S. Naamane, Z. Rais, M. Chaouch, Incorporation of wastewater sludge treated by water washout in cement, J. Mater. Environ. Sci. 5 (2014) 2515-2521.

[7] E. Kendir, E. Kentel, F.D. Sanin, Evaluation of heavy metals and associated health risks in a metropolitan wastewater treatment plant's sludge for its land application, Hum. Ecol. Risk Assess. 21 (2015) 1631-1643, https://doi.org/10.1080/10807039. 2014.966590.

[8] A.K. Venkatesan, R.U. Halden, Wastewater treatment plants as chemical observatories to forecast ecological and human health risks of manmade chemicals, Sci. Rep. 4 (2015) 3731, https://doi.org/10.1038/srep03731.

[9] K. Bondarczuk, A. Markowicz, Z. Piotrowska-Seget, The urgent need for risk assessment on the antibiotic resistance spread via sewage sludge land application, Environ. Int. 87 (2016) 49-55, https://doi.org/10.1016/j.envint.2015.11.011.

[10] N. Gupta, S.S. Gaurav, A. Kumar, Molecular basis of aluminium toxicity in plants: a review, AJPS 04 (2013) 21-37, https://doi.org/10.4236/ajps.2013.412A3004.

[11] C. Exley, Aluminum should now be considered a primary etiological factor in Alzheimer's disease, ADR 1 (2017) 23-25, https://doi.org/10.3233/ADR-170010.

[12] M.A. Tantawy, Characterization and pozzolanic properties of calcined alum sludge, Mater. Res. Bull. 61 (2015) 415-421, https://doi.org/10.1016/j.materresbull.2014. 10.042 .

[13] A.L.G. Gastaldini, M.F. Hengen, M.C.C. Gastaldini, F.D. do Amaral, M.B. Antolini, T. Coletto, The use of water treatment plant sludge ash as a mineral addition, Constr. Build. Mater. 94 (2015) 513-520, https://doi.org/10.1016/j.conbuildmat. 2015.07.038.

[14] S.E. Hagemann, A.L.G. Gastaldini, M. Cocco, S.L. Jahn, L.M. Terra, Synergic effects of the substitution of Portland cement for water treatment plant sludge ash and ground limestone: technical and economic evaluation, J. Clean. Prod. 214 (2019) 916-926, https://doi.org/10.1016/j.jclepro.2018.12.324.

[15] J.J. de Oliveira Andrade, M.C. Wenzel, G.H. da Rocha, S.R. da Silva, Performance of rendering mortars containing sludge from water treatment plants as fine recycled aggregate, J. Clean. Prod. 192 (2018) 159-168, https://doi.org/10.1016/j.jclepro. 2018.04.246.

[16] ICONTEC, NTC121 - Especificación de desempeño para cemento hidráulico, ICONTEC, 2017 (Accessed September 17, 2019), https://tienda.icontec.org/ producto/ntc121-2/.

[17] ASTM, C1157/C1157M - 17 Performance Specification for Hydraulic Cement,
ASTM International, 2017, https://doi.org/10.1520/C1157_C1157M-17.

[18] ASTM, C778-17 Specification for Standard Sand, ASTM International, 2017, https://doi.org/10.1520/C0778-17.

[19] Ministerio de Ambiente, Vivienda y Desarrollo Territorial, Resolución 2115, (2007).

[20] D. Vouk, D. Nakic, N. Stirmer, C. Cheeseman, Influence of combustion temperature on the performance of sewage sludge ash as a supplementary cementitious material, J. Mater. Cycles Waste Manage. 20 (2018) 1458-1467, https://doi.org/10.1007/ s10163-018-0707-8.

[21] S. Naamane, Z. Rais, M. Lachquar, M. Taleb, Characterization of calcined sewage sludge for its incorporation in cement, J. Mater. Environ. Sci. 5 (2014) 2212-2216.

[22] ASTM, C109/C109M - 16a Test Method for Compressive Strength of Hydraulic Cement Mortars (Using 2-in. Or [50-mm] Cube Specimens), ASTM International, 2016, https://doi.org/10.1520/C0109_C0109M-16A.

[23] M. Pérez-Carrión, F. Baeza-Brotons, J. Payá, J.M. Saval, E. Zornoza, M.V. Borrachero, P. Garcés, Potential use of sewage sludge ash (SSA) as a cement replacement in precast concrete blocks, Mater. Construcc. 64 (2014) e002, https:// doi.org/10.3989/mc.2014.06312.

[24] ABNT NBR, 15895 Materiais pozolânicos - Determinação do teor de hidróxido de cálcio fixado - Método Chapelle modificado, ABNT NBR, n.d. https://www.normas. com.br/visualizar/abnt-nbr-nm/30128/abnt-nbr15895-materiais-pozolanicosdeterminacao-do-teor-de-hidroxido-de-calcio-fixado-metodo-chapelle-modificado (Accessed September 17, 2019).

[25] K. Scrivener, R. Snellings, B. Lothenbach, A Practical Guide to Microstructural Analysis of Cementitious Materials, CRC Press, 2018.

[26] W. Navidi, Statistics for Engineers and Scientists, 3 edition, McGraw-Hill Science/ Engineering/Math, New York, 2010.

[27] M. Raverdy, F. Brivot, A.M. Paillere, R. Dron, Appreciation de l'activite pouzzolanique des constituants secondaires, Paris, France (1980), pp. 36-41.

[28] T. Ahmad, K. Ahmad, M. Alam, Investigating calcined filter backwash solids as supplementary cementitious material for recycling in construction practices, Constr. Build. Mater. 175 (2018) 664-671, https://doi.org/10.1016/j.conbuildmat.2018. 04.227.

[29] D. Sánchez, Tecnologia del concreto y del mortero, 1st. edition, Bhandar Ediciones LTDA, Santa fé de Bogotá, 2013.

[30] ASTM, C618-19 Specification for Coal Fly Ash and Raw or Calcined Natural Pozzolan for Use in Concrete, ASTM International, 2019, https://doi.org/10.1520/ C0618-19.

[31] M. Gener Rizo, J.M. Alonso Lavernia, Influencia de la composición mineralógica de puzolanas naturales en las propiedades de los cementos con adiciones, Mater. construcc. 52 (2002) 73-77, https://doi.org/10.3989/mc.2002.v52.i267.327.

[32] V.S. Ramachandran, Concrete Admixtures Handbook: Properties, Science and Technology, William Andrew, 1996.

[33] S. De Carvalho Gomes, J.L. Zhou, W. Li, G. Long, Progress in manufacture and properties of construction materials incorporating water treatment sludge: a review, Resources, Conserv. Recycl. 145 (2019) 148-159, https://doi.org/10.1016/j. resconrec.2019.02.032.

[34] F. Rajabipour, E. Giannini, C. Dunant, J.H. Ideker, M.D.A. Thomas, Alkali-silica reaction: current understanding of the reaction mechanisms and the knowledge gaps, Cem. Concr. Res. 76 (2015) 130-146, https://doi.org/10.1016/j.cemconres. 2015.05.024.

[35] A. Tironi, M.A. Trezza, E. Irassar, A.N. Scian, Thermal activation of bentonites for their use as pozzolan, Revista de la Construccion. 11 (2012) 44-53.

[36] Mdel P. Durante Ingunza, G. Camarini, F. Murilo Silva da Costa, Performance of mortars with the addition of septic tank sludge ash, Constr. Build. Mater. 160 (2018) 308-315, https://doi.org/10.1016/j.conbuildmat.2017.11.053.

[37] K. Pospíšil, A. Frýbort, A. Kratochvíl, J. Macháčková, Scanning Electron microscopy method as a tool for the evaluation of selected materials microstructure, ToTS 1 (2008) 13-20, https://doi.org/10.5507/tots.2008.002. 